\title{
COMPARISON OF ASTER AND SRTM DIGITAL ELEVATION MODELS AT ONE-ARC-SECOND RESOLUTION OVER TURKEY
}

\author{
İ́brahim Öztuğ BİLDİi̇Ċ, 2Ramazan Alpay ABBAK \\ 1,2Selcuk University, Department of Geomatics Engineering, Campus, Selcuklu, Konya, TURKEY \\ ${ }^{1}$ bildirici@selcuk.edu.tr, 2aabbak@selcuk.edu.tr
}

(Geliş/Received: 08.08.2016; Kabul/Accepted in Revised Form: 11.11.2016)

\begin{abstract}
In February 2000, the "Shuttle Radar Topography Mission (SRTM)" satellite captured elevation data by scanning the Earth landmasses between the $60^{\circ}$ North and South latitudes. After the mission of 11 days, the collected data were processed, and a Digital Elevation Model (DEM) within one arc-second resolution for United States and three arc-second resolutions for the other parts of the globe was created and published on the NASA servers. Recently, a global SRTM DEM with one-arc-second resolution has been released. Additionally, ASTER (Advanced Spaceborne Thermal Emission and Reflection Radiometer) is a sensor boarded on the Terra satellite in 1999. The sensor has been collecting satellite imagery since 2000. The ASTER GDEM at one-second resolution was released to the public, which is the most complete DEM of the earth ever made. In this study, SRTM and ASTER DEMs with one arc-second resolution over Turkish territory was evaluated by means of a local DEM produced from $1: 25 \mathrm{~K}$ national topographic maps. Results show that the accuracy of the SRTM DEM is better than the ASTER GDEM with respect to the local DEM.
\end{abstract}

Key Words: ASTER GDEM, Evaluation, Digital elevation model, SRTM, 1:25K topographic maps.

\section{Saniye Çözünürlüklü ASTER ve SRTM Sayısal Yükseklik Modellerinin Türkiye'de Karşılaştırması}

ÖZ: 2000 yılında SRTM (Shuttle Radar Topography Mission) uydusu yeryüzünü $60^{\circ}$ kuzey ve güney enlemleri arasını tarayarak yükseklik bilgisi elde etmiştir. 11 günlük görevinden sonra toplanan veriler işlenmiş ve $\mathrm{ABD}$ için 1 saniye diğer ülkeler için 3 saniye çözünürlükte olmak üzere bir Sayısal Yükseklik Bilgisi üretilmiş ve NASA sunucularında yayınlanmıştır. Son zamanlarda 1 saniye çözünürlüklü global SRTM SYM yayınlanmaya başlamıştır. Ayrıca, ASTER (Advanced Spaceborne Thermal Emission and Reflection Radiometer) Terra uydusuna 1999 yılında montelenmiş bir algılayıcıdır. Bu algılayıcı 2000 yılından beri uydu görüntüsü toplamaktadır. 1 saniye çözünürlüklü ASTER SYM dünyanın en geniş kapsamlı SYM'si olup kullanıma açılmıştır. Bu çalışmada 1 saniye çözünürlüklü ASTER ve SRTM SYM'ler Türkiye'de 1:25 000 ölçekli topografik haritalarda türetilen yerel SYM ile değerlendirilmiştir. Sonuçlar, SRTM SYM'nin ASTER SYM'ye göre daha iyi olduğunu göstermektedir.

Anahtar Kelimeler: ASTER SYM, Değerlendirme, Sayısal yükseklik modeli, 1:25000 ölçekli topografik harita.

\section{INTRODUCTION}

Digital Elevation Model (DEM) is a computer representation of physical surface of the Earth. DEM is utilized by a wide range of geospatial applications such as gravity interpolation in geodesy, risk assessments in Geographic Information Systems, run-off simulations in Hydrology, morphologic analyses in Geology etc.

\section{DOI: 10.15317/Scitech.2017.66}


Like other models, DEMs are subject to errors (e.g. systematic or random). Thus, end users of DEMs should be aware of the accuracy of the DEM in a project area. Hence DEM should be evaluated by means of the ground truth data such as local DEM or leveling points.

Recently, SRTM (Shuttle Radar Topography Mission) and ASTER (Advanced Space-borne Thermal Emission and Reflection Radiometer) DEMs at one arc-second resolution are released to the public on the Internet. Accuracies of these DEMs are subject to investigation for end users over the world (Jing et al, 2014; Hirt et al 2010; Rexer and Hirt 2014). Moreover, Bildirici et al (2016) compares ASTER DEM and an enhanced version of SRTM3 (3 arc-second resolution) in the same study area. In this study, accuracies of the both DEMs within one-arc resolution (SRTM1) were assessed with help of local DEM obtained from 1:25K scaled topographic maps of Turkish territory. It is concluded that SRTM DEM is superior to ASTER DEM over Turkey from the point of the accuracy of height data.

The present paper starts with brief review of SRTM and ASTER missions. Then comparison methodology is discussed shortly. Subsequently, numerical applications for the comparison of both DEMs are performed in Turkey. Finally concluding remarks were outlined for further studies.

\section{MATERIALS AND METHOD}

\section{Study area}

Our study area lies on Turkish territory which covers 780000 square $\mathrm{km}$. The study area is delimitated by $36^{\circ}-42^{\circ}$ northern latitudes and by $26^{\circ}-45^{\circ}$ western longitudes. Maximum and minimum heights in the area are $5197 \mathrm{~m}$ at the summit of Agri (Ancient ararat) mountain and $0 \mathrm{~m}$ at the sea side, respectively. The average height is approximately $1000 \mathrm{~m}$ for the area. This area was selected for our study because it is one of the most complicated regions over the world from the point of the view of topographic variation. Figure 1 and 2 show the topography of the study area together with test data.

\section{SRTM DEM}

The SRTM project was jointly realized by NASA, the National Imagery and Mapping Agency (NIMA), the German Space Agency (DLR) and Italian Space Agency (ASI). The mission collected threedimensional image of the Earth's land surface by exploiting the radar interferometry, which matches two radar images in order to derive the elevation information. Then, the images were transformed to a global DEM, which is spanning from $60^{\circ} \mathrm{N}$ to $56^{\circ} \mathrm{S}$ over the world.

The SRTM DEM does not include any bathymetric data which means that water bodies (i.e. ocean and sea) are attributed with " 0 " $\mathrm{m}$. The vertical accuracy of the DEM is globally estimated to be $16 \mathrm{~m}$ at the $90 \%$ confidence level. The detailed documentation and technical specification of the SRTM DEM can be found at NASA servers (SRTM, 2016a).

SRTM Data Products is distributed freely to the public via Internet data portals such as Earth Explorer (USGS, 2016), and NASA Jet Propulsion Laboratory (JPL) Data Distribution Center (http://dds.cr.usgs.gov/srtm/version2_1). The level of processing and the resolution of the data will vary. Currently following data products are available at Earth Explorer (SRTM, 2016b):

- SRTM Non-Void Filled elevation data were processed from raw C-band radar signals spaced at intervals of 1 arc-second at NASA's Jet Propulsion Laboratory (JPL). This version was then enhanced by the National Geospatial-Intelligence Agency (NGA). Data for regions outside the United States were sampled at 3 arc-seconds (approximately 90 meters) using a cubic convolution resampling technique for public distribution.

- SRTM Void Filled elevation data are the result of additional processing to address areas of missing data or voids in the SRTM Non-Void Filled collection. The voids occur in areas where the initial processing did not satisfy quality specifications. Since SRTM data are one of the most 
widely used elevation data sources, the NGA filled the voids by using interpolation techniques. The resolution for SRTM Void Filled data is the same as the SRTM Non-Void Filled Data.

- SRTM 1 Arc-Second Global elevation data is the worldwide coverage of void filled data at a resolution of 1 arc-second (30 meters), and presented to the public. Some tiles may still contain voids. It should be noted that tiles above $50^{\circ}$ north and below $50^{\circ}$ south latitude are sampled at a resolution of 2 arc-second by 1 arc-second.

Due to the worldwide coverage and high resolution, SRTM 1 dataset is used in current study data.

SRTM data with a regularly spaced grid of elevation points can be downloaded from Earth Explorer in three file formats:

- Digital Terrain Elevation Data (DTED) is a standard mapping format designed by the NGA. Each file or cell contains a matrix of vertical elevation values spaced at regular horizontal intervals measured in geographic coordinates

- Band interleaved by line (BIL) is a binary raster format with an accompanying header file which describes the layout and formatting of the file.

- Georeferenced Tagged Image File Format (GeoTIFF) is a TIFF file with embedded geographic information.

SRTM data specifications are given in Table 1 in comparison to ASTER GDEM.

Table 1. Specifications of SRTM and ASTER DEMs

\begin{tabular}{|l|ll|}
\hline Features & SRTM & ASTER \\
\hline Projection & Geographic & Geographic \\
Horizontal Datum & WGS84 & WGS84 \\
Vertical Datum & EGM96 & EGM96 \\
Vertical Units & Meters & Meters \\
Spatial Resolution & 1 arc-second for globe & 1 arc-second \\
& 3 arc-seconds for globe & \\
Data Size & 1 degree tiles & 1 degree tiles \\
File Format & HGT, DTED, BIL, GeoTIFF & GeoTIFF \\
\hline
\end{tabular}

\section{ASTER GDEM}

ASTER, which is an observing sensor, was placed on the satellite "Terra" in December 1999. This sensor is an achievement of an international joint project between NASA and Japanese Ministry of Economy, Trade and Industry (METI).

The DEM was generated from a stereo image pair acquired with nadir and backward angles over the same area, and then it was released in 2009. This strategy provided a global DEM with enhanced accuracy due to multiple images. As a result of the project, ASTER GDEM covers all land area ranging from $83^{\circ} \mathrm{N}$ to $83^{\circ} \mathrm{S}$ even in steep mountainous areas.

ASTER GDEM is available in geo-tiff format by $1^{\circ} \times 1^{\circ}$ tiles at 1 arc-second resolution. Vertical and horizontal datum of the DEM are EGM96 and WGS84, respectively. Zero for water surfaces (i.e. sea and ocean) and -9999 for voids are assigned in the data files. Vertical accuracy of the DEM is estimated to be 7-14 $\mathrm{m}$ over the United States. The detailed documentation and technical specification of ASTER GDEM can be found at Japanese Space System server (ASTER 2016).

ASTER data specifications are given in Table 1 in comparison to SRTM. 


\section{Local Height Data}

For local heights digitized contour lines of $25 \mathrm{~K}$ topographic maps are used. In order to create a local DEM, General Command of Mapping (GCM) in Turkey vectorized the contour lines of $25 \mathrm{~K}$ maps. The data was distributed in CAD (Computer Aided Design) files, each sheet being an individual file. The authors obtained a collection of these files within a previous project (Bildirici et al 2009), and utilized this data set in this study. Today, GCM distributes DTED (Digital Terrain Elevation Data) files in one arcsecond resolution, which is generated from the digitized contour lines mentioned above. Accuracy of the DEM is estimated to be $\sim 2 \mathrm{~m}$ in the vertical direction by Ozturk and Kocak (2007). The DEM from GCM is not free of charge.

The point density on contour lines is very high due to automatic vectorization. A point thinning process is necessary to use this data set properly. The coordinate system of the DEM is UTM on European Datum 1950, and its vertical datum is mean sea level at Antalya tide gauge. In order to perform a comparison, point density on contour lines is to be reduced, and horizontal and vertical datum conversions are performed.

\section{Comparison Methodology}

For the statistical evaluation local DEM is assumed ground truths. Before the height comparison, two preprocessing steps are performed. After point thinning mentioned in the previous section local height data is undergone to horizontal datum transformation. Thereafter local points are transformed to WGS84 ellipsoid with geographical coordinates. Each point is in local height data is interpolated with IDW method by using global DEMs. Doing so, for each point, local height, height from SRTM, and height from ASTER are prepared.

In geodetic literature, two types of height data are not comparable directly due to systematic errors (e.g. datum shifts). Thus a corrector surface is used to remove systematic errors between data before detailed discussion. Corrector surfaces which area from a simple linear model to more sophisticated similarity transformation model can be found in literature (Kotsakis and Sideris, 1999; Abbak, 2014).

Such a comparison is based on a traditional method as follows,

$$
H_{L O C A L}-H_{G L O B A L}=A x-\varepsilon
$$

where $\mathbf{A}$ is a design matrix, $\mathbf{x}$ is a vector of unknown parameters, $\varepsilon$ is the random noise term. The parametric model is assumed to absorb all systematic errors.

In this study, four parameters model was used because it gives more reasonable results. Four parameters model,

$a=\left[\begin{array}{ll}\cos & \cos \\ \cos & \sin \\ \sin & \\ 1 & \end{array}\right]$

where $\varphi$ and $\lambda$ are geographical coordinates of a check point. The vector a is extended for each checkpoint, then the design matrix $\mathbf{A}$ is obtained. Subsequently, unknown parameters are solved by Least Squares (LS) approach. Finally, the Root Mean Square Errors (RMSE) is calculated that are supposed to be the accuracy of global DEM. How ever, the RMSE value still contains errors of the local DEM.

For all steps in comparison in-house programs developed in C programming language are used. 


\section{APPLICATION}

In this section, validation of ASTER and SRTM DEMs were performed by means of the local DEM. For this purpose, local DEM that covers 37 of $25 \mathrm{~K}$ map sheets were selected to represent various topographic features throughout the country. After thinning process mentioned above, the total number of points for all sheets are about 3770 421, being 101903 points for each sheet in average.

The evaluation steps are as follows:

- ASTER GDEM tiles were downloaded in Geo-TIFF format. By using GDAL programming package (http://www.gdal.org), data files are converted into binary grid files, in which heights are recorded as 2 bytes integer sequentially.

- $\quad$ SRTM 1 tiles were downloaded from Earth Explorer in binary grid files (BIL format).

- The points on digitized contour lines are thinned with $30 \mathrm{~m}$ distance criterion. Thereafter projection and datum conversion were undertaken.

- For each point within ground truth data neighboring 4 points in grid file (ASTER or SRTM) are found. By using IDW (Inverse Distance Weighting) interpolation method the height of the point is determined (Gruver, 2016). For each 25K file, a file with geographical coordinates, local heights and interpolated heights are formed. By using this file a vertical datum conversion is performed and heights are compared. For this step another program was developed in C language programming language.

- Finally Global DEMs were matched against to Local DEM in terms of accuracy. In order to avoid systematic errors (e.g. datum shifts), two types of heights (Local DEM and ASTER/SRTM DEMs) were compared with four parameters corrector surface model.

Table 2 show s results that are obtained from four parameters corrector surface model. According to the table, SRTM is better than ASTER, but in some rough topography, ASTER is superior to SRTM in regarding to the accuracy of height data. In the table the RMS values where ASTER is better than SRTM is indicated with bold text. In seven of 37 sheets ASTER is better. The distribution of the test sheets over Turkey is depicted in Figure 1 and 2.

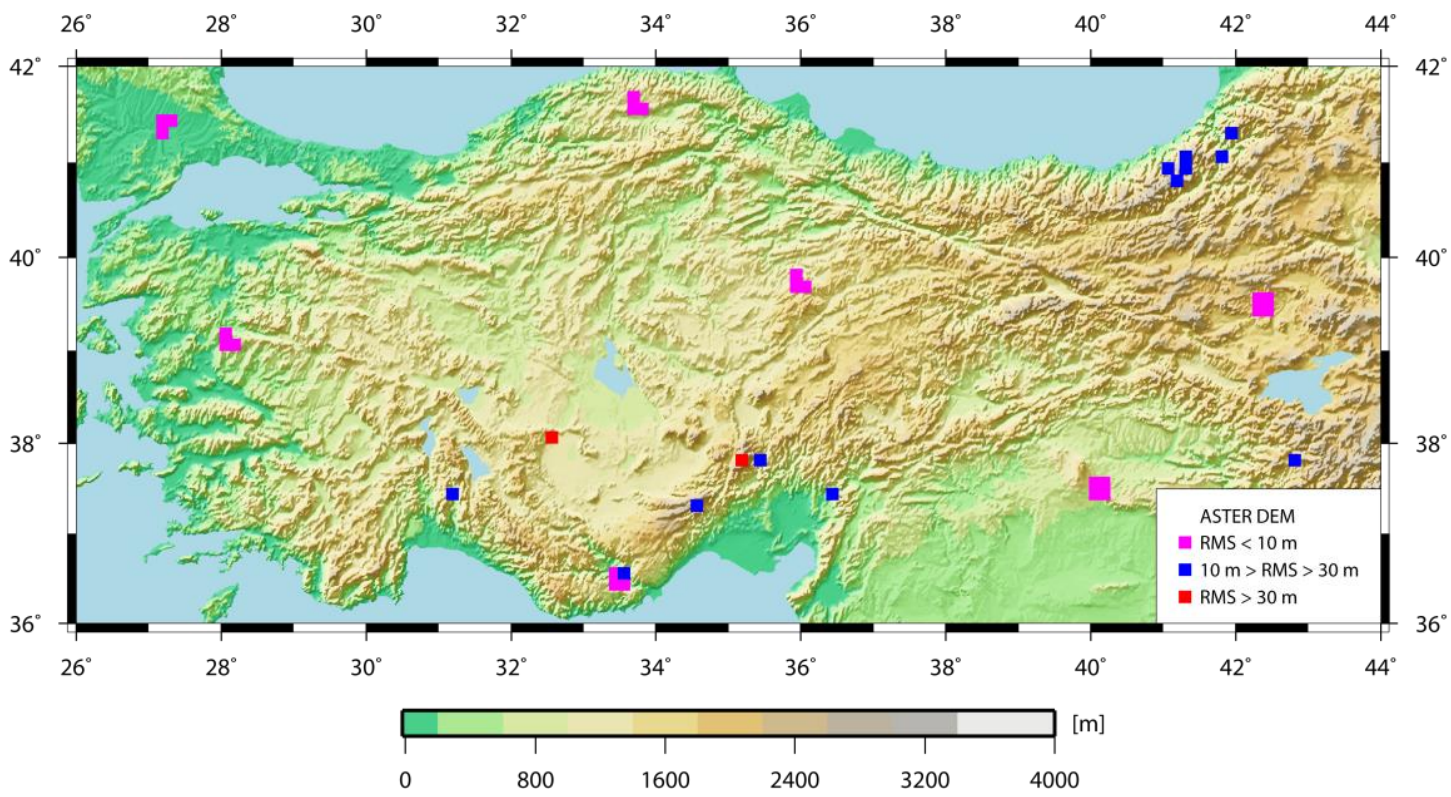

Figure 1. ASTER GDEM validation over Turkey 
In order to identify what extent affects four parameters corrector surface model on the accuracy, we directly compared the SRTM and local DEMs. It was concluded that improvements in accuracy change from $2 \mathrm{~cm}$ to $6 \mathrm{~m}$, in average of $1 \mathrm{~m}$. Hence corrector surface models gave us more optimistic results.

In Figure 1 and 2 the distribution of the test data over Turkey and obtained results are vis ualized over Turkish territory.

Table 2. Validation of SRTM and ASTER DEMs with help of the local DEM (unit: meter)

\begin{tabular}{|c|c|c|c|c|c|c|c|c|}
\hline \multirow[t]{2}{*}{ Sheet } & \multicolumn{4}{|c|}{ ASTER } & \multicolumn{4}{|c|}{ SRTM } \\
\hline & Min & Max & Mean & RMS & Min & Max & Mean & RMS \\
\hline e31c4 & -36.02 & 53.97 & -0.01 & 8.14 & -31.17 & 35.95 & 0.00 & 5.60 \\
\hline e31d2 & -36.97 & 45.65 & -0.02 & 7.81 & -30.83 & 30.30 & -0.01 & 5.62 \\
\hline e31d3 & -38.28 & 60.03 & -0.01 & 7.51 & -24.03 & 25.47 & 0.02 & 4.72 \\
\hline $\mathrm{f} 18 \mathrm{a} 2$ & -23.26 & 20.89 & 0.03 & 4.00 & -12.93 & 16.10 & 0.00 & 2.75 \\
\hline $\mathrm{f} 18 \mathrm{a} 3$ & -25.58 & 19.76 & -0.00 & 3.72 & -12.48 & 12.57 & 0.00 & 2.46 \\
\hline $\mathrm{f} 18 \mathrm{~b} 1$ & -19.28 & 26.89 & -0.00 & 3.80 & -17.11 & 15.92 & 0.00 & 2.82 \\
\hline $\mathrm{f} 46 \mathrm{c} 4$ & -148.85 & 109.28 & 0.02 & 15.97 & -181.15 & 164.41 & 0.01 & 23.87 \\
\hline f47b3 & -146.73 & 137.06 & -0.01 & 15.35 & -186.88 & 137.79 & 0.00 & 16.52 \\
\hline $\mathrm{f} 47 \mathrm{c} 4$ & -215.63 & 217.23 & 0.01 & 18.71 & -192.31 & 161.87 & 0.00 & 19.02 \\
\hline g46a1 & -198.62 & 103.82 & -0.00 & 17.26 & -211.88 & 109.76 & 0.01 & 17.45 \\
\hline g46a3 & -215.48 & 124.22 & -0.00 & 18.84 & -108.75 & 135.27 & 0.02 & 12.42 \\
\hline g46b1 & -168.99 & 109.54 & -0.01 & 23.47 & -117.31 & 89.36 & -0.02 & 17.67 \\
\hline i35b3 & -41.33 & 38.81 & -0.00 & 7.58 & -33.13 & 26.45 & 0.02 & 5.53 \\
\hline i35c2 & -43.85 & 54.24 & 0.00 & 8.28 & -29.71 & 28.81 & -0.01 & 5.91 \\
\hline i36d1 & -43.07 & 74.40 & -0.00 & 9.03 & -23.43 & 32.81 & 0.02 & 6.25 \\
\hline $\mathrm{i} 48 \mathrm{c} 3$ & -42.27 & 34.74 & -0.00 & 6.82 & -39.80 & 31.51 & 0.00 & 5.09 \\
\hline $\mathrm{i} 48 \mathrm{c} 4$ & -29.95 & 43.86 & -0.00 & 6.62 & -23.62 & 21.32 & 0.00 & 4.69 \\
\hline j20d1 & -42.42 & 55.70 & 0.02 & 8.00 & -35.55 & 32.39 & 0.00 & 7.00 \\
\hline j20d3 & -42.41 & 78.33 & -0.00 & 6.71 & -27.66 & 33.99 & 0.00 & 5.80 \\
\hline $\mathrm{j} 20 \mathrm{~d} 4$ & -78.92 & 121.50 & 0.01 & 9.32 & -50.87 & 68.57 & 0.00 & 7.02 \\
\hline j48b1 & -35.67 & 41.28 & -0.01 & 7.08 & -26.86 & 28.83 & 0.00 & 5.46 \\
\hline $\mathrm{j} 48 \mathrm{~b} 2$ & -33.21 & 43.94 & -0.00 & 6.35 & -26.32 & 24.74 & 0.00 & 4.92 \\
\hline $129 \mathrm{~d} 4$ & -135.24 & 228.32 & 0.01 & 41.62 & -129.73 & 207.90 & 0.03 & 40.90 \\
\hline $\mathrm{m} 34 \mathrm{a} 3$ & -496.22 & 409.43 & -0.02 & 64.91 & -511.40 & 410.66 & 0.00 & 77.94 \\
\hline $\mathrm{m} 34 \mathrm{~b} 3$ & -204.69 & 217.68 & -0.01 & 23.36 & -190.41 & 317.72 & -0.06 & 31.30 \\
\hline $\mathrm{m} 44 \mathrm{~d} 3$ & -58.35 & 27.14 & 0.01 & 4.70 & -21.14 & 21.75 & 0.00 & 3.99 \\
\hline $\mathrm{m} 44 \mathrm{~d} 4$ & -16.10 & 20.14 & -0.01 & 3.59 & -13.59 & 14.52 & 0.00 & 2.84 \\
\hline $\mathrm{m} 49 \mathrm{~b} 4$ & -175.29 & 226.22 & 0.02 & 17.66 & -181.50 & 404.43 & -0.01 & 15.53 \\
\hline $\mathrm{n} 26 \mathrm{a} 2$ & -230.14 & 211.00 & -0.00 & 15.64 & -185.47 & 225.89 & -0.03 & 12.53 \\
\hline n33a4 & -225.38 & 180.66 & -0.00 & 27.78 & -239.78 & 215.03 & 0.01 & 31.10 \\
\hline $\mathrm{n} 36 \mathrm{~b} 2$ & -257.09 & 175.50 & -0.00 & 19.87 & -233.74 & 146.93 & 0.00 & 19.30 \\
\hline n44a1 & -93.93 & 29.56 & -0.00 & 5.64 & -96.04 & 19.61 & -0.01 & 4.61 \\
\hline $\mathrm{n} 44 \mathrm{a} 2$ & -35.10 & 62.95 & 0.00 & 7.77 & -23.57 & 27.96 & 0.00 & 5.48 \\
\hline o30c3 & -53.39 & 46.89 & -0.01 & 9.27 & -56.68 & 34.39 & 0.00 & 6.72 \\
\hline o31d4 & -61.84 & 69.27 & -0.00 & 10.83 & -50.87 & 63.87 & -0.01 & 8.20 \\
\hline p30b2 & -57.39 & 64.37 & -0.00 & 10.93 & -48.22 & 53.53 & -0.01 & 7.05 \\
\hline p31a1 & -53.37 & 62.14 & -0.01 & 8.29 & -53.69 & 40.17 & 0.00 & 6.57 \\
\hline
\end{tabular}




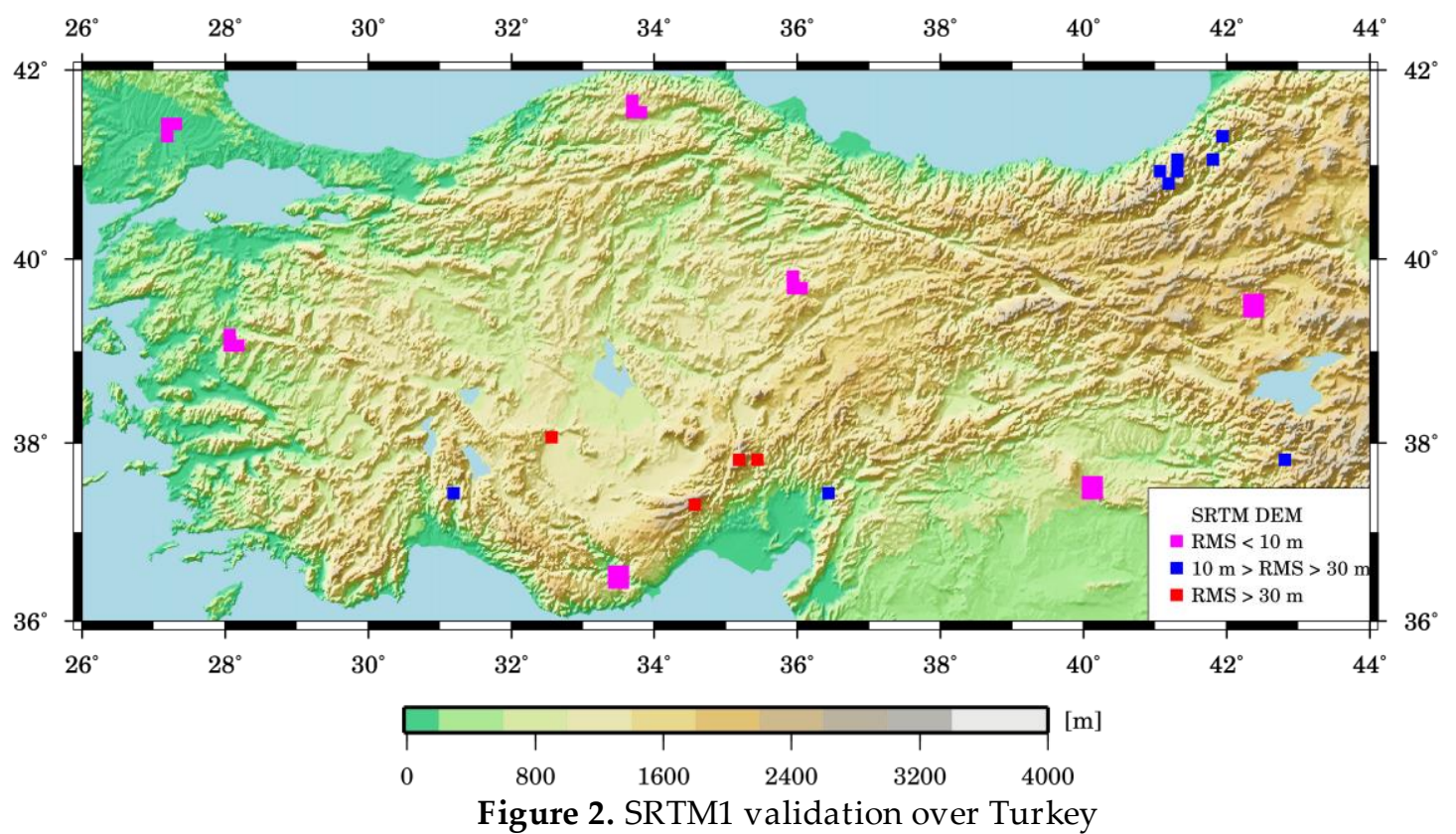

Among the 37 test sheets M34A3 is the one with highest RMS values after ASTER and SRTM validation. For this reason the topography of this region and differences between local and ASTER, and local and SRTM are depicted in Figures 3 to 5.

M34a3 Local Data

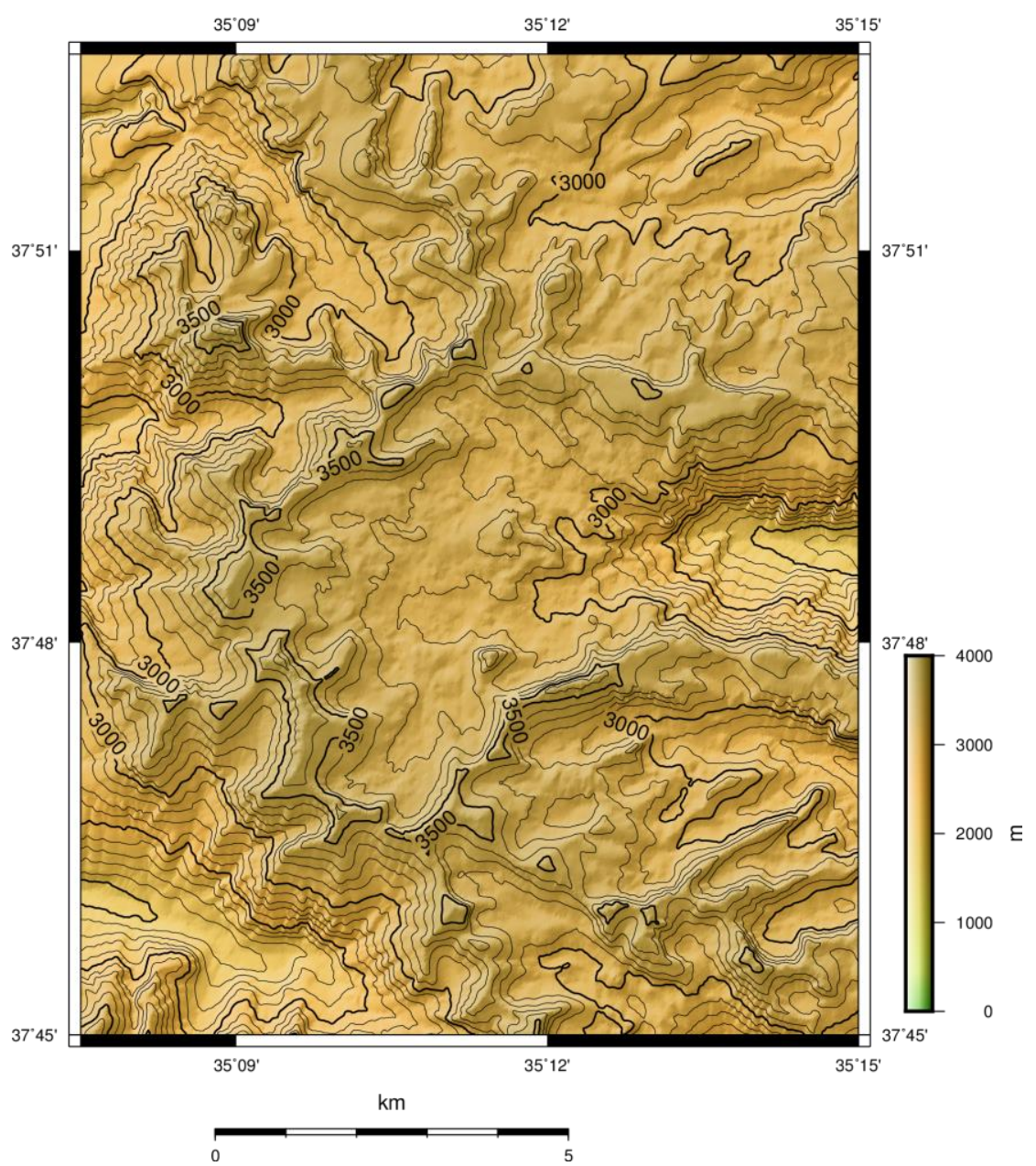

Figure 3. Topography of the M34A3 based on local data 


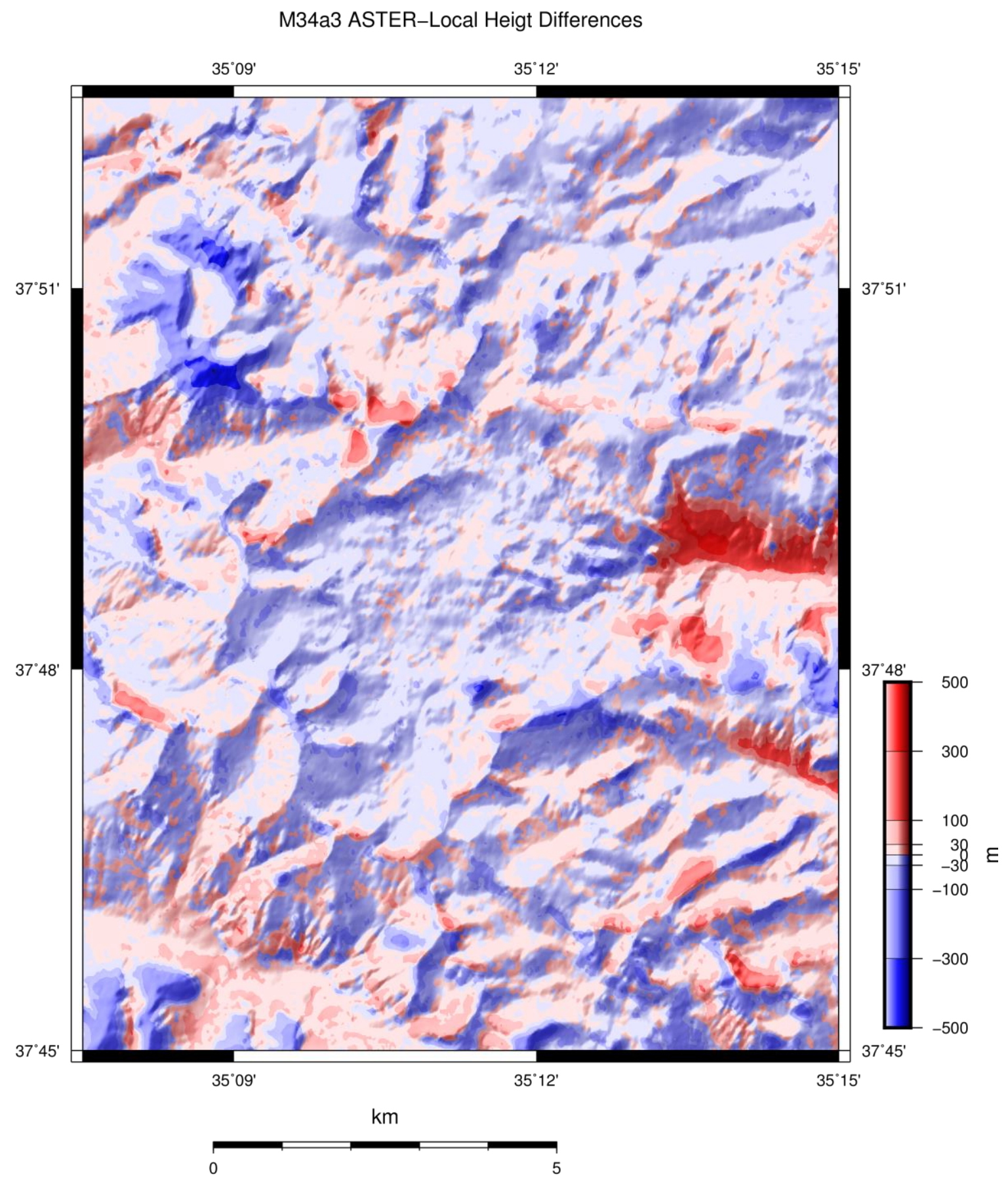

Figure 4. Differences between Local and ASTER GDEM heights 


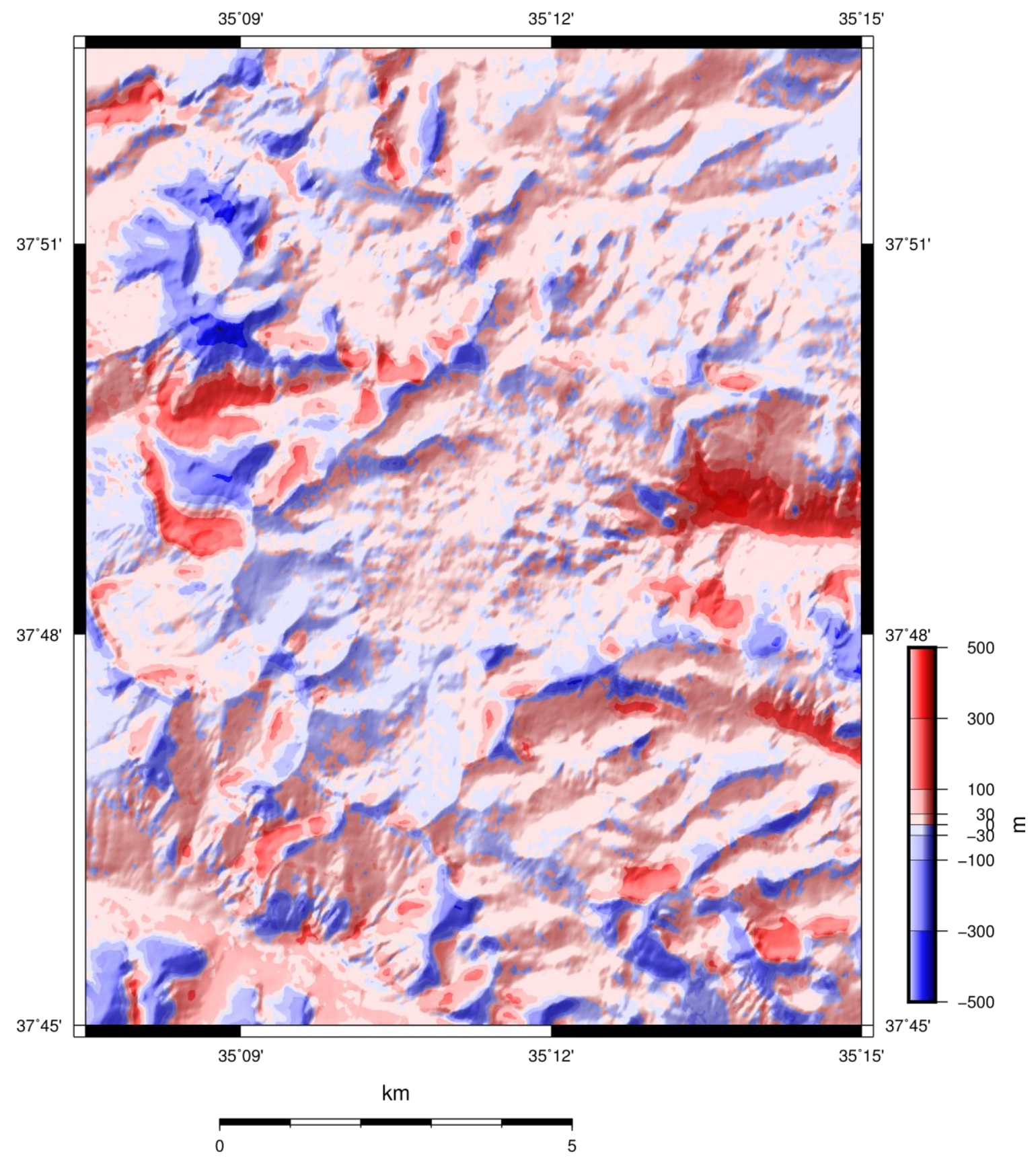

Figure 5. Differences between Local and SRTM heights

\section{CONCLUSIONS}

In this study, SRTM and ASTER DEMs at one arc second resolution were compared in terms of a local DEM which is produced from 1:25K topographic map sheets over the Turkish territory. For this purpose, 37 map sheets, which are covers different characteristic topography, were selected.

According to our numerical results, ASTER GDEM is better than SRTM DEM in some rough areas (in 7 map sheets) whereas SRTM gives more reasonable results in other parts of test area. Considering overall statistics, SRTM DEM is superior to ASTER GDEM from the point of view of accuracy. In a very rough topography (m34b3 map sheet), maximum RMSs for ASTER and SRTM DEMs are about $65 \mathrm{~m}$ and $78 \mathrm{~m}$, respectively. At the end, we can say that the both DEMs are beneficial for geospatial applications 
such as GIS, cartography, remote sensing etc., if the accuracies that are found in this study are acceptable.

\section{REFERENCES}

Abbak, R. A., 2014, "Effect of ASTER DEM on The Prediction of Mean Gravity Anomalies: A Case Study Over The Auvergne Test Region", Acta Geodaetica et Geophysica, Vol.49(4), pp. 491-502.

ASTER, 2016, The Advanced Spaceborne Thermal Emission and Reflection Radiometer. http://gdem.ersdac.jspacesystems.or.jp accessed: August 2016.

Bildirici, I. O., Abbak, A. R., Ulugtekin, N., 2016, “ASTER GDEM AND SRTM DEM in Turkish Territory: An Evaluation in Terms of Height Accuracy and 3D Visualization", Proceedings of 6th International Conference on Cartography and GIS, Albena, Bulgaria, ISSN: 1314-0604, Eds: Bandrova T., Konecny M., pp. 266-272, 13-17 June 2016.

Bildirici, I.O., Ustun, A., Selvi, H.Z., Abbak, R. A., Bugdayci I., 2009, “Assessment of SRTM Based on Topographic Maps in the Territory of Turkey", Cartography and Geographic Information Science, Vol. 36 (1), pp. 95-104.

Gruver, A., 2016, Cartography and Visualization, online course pages, https://www.eeducation.psu.edu/geog486/node/1877, accessed: August 2016.

Hirt, C., Filmer, M. S., Featherstone, W. E., 2010, “Comparison and Validation of The Recent Freely Available ASTER-GDEM Ver1, SRTM Ver4.1 And GEODATA DEM-9S Ver3 Digital Elevation Models Over Australia", Australian Journal of Earth Sciences, Vol.57(3), pp. 337-347.

Jing, C., Shortridge, A., Lin, S., Wu, J., 2014, “Comparison And Validation of SRTM and ASTER GDEM for A Subtropical Landscape in Southeastern China", International Journal of Digital Earth, Vol. 7(12), pp. 969-992.

Kotsakis C, Sideris M. G., 1999, “On The Adjustment of Combined GPS/Levelling/Geoid Networks". Journal of Geodesy, Vol. 73(8), pp. 412-421.

Ozturk, E., Kocak, E., 2007, “Farklı Kaynaklardan Değişik Yöntem ve Ölçeklerde Üretilen Sayısal Yükseklik Modellerinin Doğruluk Araştırması (Accuracy Assessment of Digital Elevation Models Produced in Different Scales Form Different Sources by Using Various Techniques)". Harita Dergisi, Vol. 137, pp. 25-41.

Rexer, M., Hirt, C., 2014, “Comparison of Free High Resolution Digital Elevation Data Sets (ASTER GDEM2, SRTM V2.1/V4.1) and Validation Against Accurate Heights from The Australian National Gravity Database", Australian Journal of Earth Sciences, Vol. 61(2), pp. 213-226.

SRTM (2016a), Shuttle Radar Topography Mission, http://www2.jpl.nasa.gov/srtm accessed: August 2016.

SRTM (2016b), Shuttle Radar Topography Mission, USGS Long Term Archive, https://lta.cr.usgs.gov/SRTM accessed: August 2016.

USGS (2016) Earth Explorer, http://earthexplorer.usgs.gov, accessed: August 2016. 